Japan. J. Physiol., 21, pp. 15-25, 1971

\title{
NEURAL REGULATION OF ATRIOVENTRICULAR CONDUCTION
}

\author{
Hiroshi Irisawa, * W. M. Caldwell and M. F. Wilson \\ Department of Physiology and Biophysics, West Virginia University Medical Center \\ Morgantown, West Virginia 26506, U.S.A.
}

\begin{abstract}
Summary A cardiotachometer has been devised to record the variation of the frequency of the sino-atrial node, but no apparatus has been reported which simultaneously records the frequency variations in atrioventricular conduction time and the sino-atrial node frequency. In an attempt to demonstrate how the sinus rhythm affects the A-V nodal conduction time, excitation conduction time between the right atrium and ventricle was recorded continuously by a newly devised $\mathrm{A}-\mathrm{V}$ interval meter and compared with the variation in the length of the cardiac cycle ( $\mathrm{R}-\mathrm{R}$ interval).

In the post-operative unanesthetized $\mathrm{dog}$, the respiratory variation in $\mathrm{A}-\mathrm{V}$ interval was from 7 to $13 \mathrm{msec}$ while the $\mathrm{R}-\mathrm{R}$ interval ranged from 350 to $500 \mathrm{msec}$. The variations of the $A-V$ and $R-R$ intervals were in phase under nervous control but out of phase with pacing and pharmacological intervention. Both variations diminished in amplitude when the dog stood up or ate, when propranolol was administered intravenously, or when atropine was given.

In the anesthetized animal right vagal stimulation caused an abrupt lengthening of the $\mathrm{R}-\mathrm{R}$ interval after one second or less, while left vagal stimulation usually prolonged the $A-V$ interval after more than one second. Stimulation of the left stellate ganglion resulted in a shorter A-V conduction time without a change in the $R-R$ interval, while stimulation of the right stellate ganglion generally caused tachycardia.
\end{abstract}

Neural control of the heart rate is mediated by vagal and sympathetic outflow to the cardiac pacemaker tissues (ANZOLA and RUSHMER, 1956; RUSHMER and WeST, 1957). Both the vagus and the sympathetic nerves are known to innervate the $\mathrm{A}-\mathrm{V}$ node and to influence atrioventricular conduction (KUNTZ,

Received for publication October 27, 1970

入澤: 宏

* Present address: Department of Physiology, School of Medicine, Hiroshima University, Hiroshima, Japan.

This research was supported in part by research grant HE 10234-03 from the National Institute of Health. 
1953; Shipley and GregG, 1945). Stimulation of the vagal nerve produces a prolongation of the $\mathrm{P}-\mathrm{Q}$ interval and finally causes an $\mathrm{A}-\mathrm{V}$ block, while stimulation of the stellate ganglion shortens the P-Q interval (Priola and Randall, 1964; Randall and RoHSE, 1956; RANDALl et al., 1963; Ulmer and RANDALL, 1961; Wallace, 1963; Wallace and SarnofF, 1964). The results of these previous studies are based on the manual measurement of $\mathrm{P}-\mathrm{Q}$ intervals in the conventional electrocardiogram. Such measurement requires a timeconsuming effort to evaluate the consecutive changes in $\mathrm{A}-\mathrm{V}$ conduction time and has limitations with respect to evaluating rapid changes.

The present experiments have been designed to record the A-V interval continuously using a recently devised interval meter. The magnitude and time course of the variation in $\mathrm{A}-\mathrm{V}$ conduction time were evaluated with both the presence and absence of vagal and sympathetic nerve influences in both anesthetized and unanesthetized dogs.

\section{METHODS}

Myocardial action potentials were obtained by placing suction electrodes on the epicardial surface of the right atrium and right ventricle (Fig. 1-A). These suction electrodes measured the monophasic potential from the atrium (A potential) and the ventricle ( $\mathrm{V}$ potential). These potentials, which ranged from 10 to $30 \mathrm{mV}$, were recorded on F.M. tape. The signals were converted to square waves by overdriven amplifiers, differentiated into pulses, and then used to switch a bistable multivibrator $\left(T_{2}\right.$ and $\left.T_{3}\right)$ producing a square wave whose duration was equal to the $\mathrm{A}-\mathrm{V}$ interval. This square wave was integrated, yielding a negative moving ramp proportional in amplitude to the duration of the $\mathrm{A}-\mathrm{V}$ interval. The output of the integrator remained at this value until the next $\mathrm{A}-\mathrm{V}$ square wave automatically reset it at zero by turning on $\mathrm{T}_{1}$. Thus each set of $\mathrm{A}-\mathrm{V}$ signals produced a DC voltage whose amplitude was proportional to the time between the initial rise of the $\mathrm{A}-\mathrm{V}$ potentials. This time was easily calibrated for recording by direct measurement with an oscilloscope or an accurate pulse generator which simulated the A-V signals. Simultaneous measurements of the instantaneous heart rate were performed by the rate meter used previously (WILSON and NiNoMIYA, 1964). The heart rate was recorded continuously as a DC output from a tachometer which triggered the rising phase of the atrial action potentials. The beat to beat interval, with a lag of one cycle, was recorded on the basis of electrical computation as indicated in the top tracing of Fig. 1-B.

The experiments were conducted using 9 dogs, 7 under sodium pentobarbital anesthesia $(35 \mathrm{mg} / \mathrm{kg}$ ) and 2 unanesthetized, in which electrodes were implanted. Bipolar electrodes were sutured on the right atrial surface so that the atrium could be driven with an electrical stimulator (Grass Model 45). Square waves having a duration of $0.5 \mathrm{msec}$ at a frequency of 7 to $10 \mathrm{~Hz}$ and approximately 10 volts 


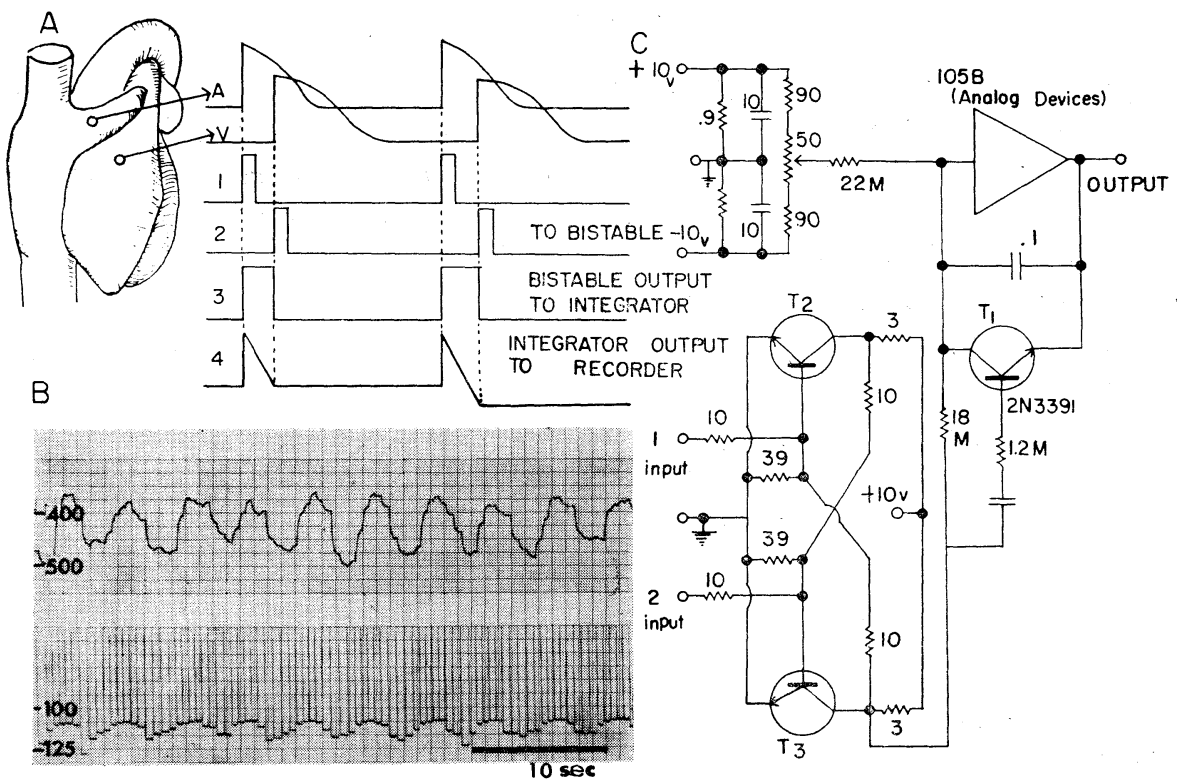

Fig. 1. Method for registering the A--V interval. A: Inset picture indicates the localization of the electrodes on the right atrium and the right ventricle. $\mathrm{A}$ and $\mathrm{V}$ are the original tracings. The pulses immediately below correspond to the onset of the action potentials $\mathrm{A}$ and $\mathrm{V}$. These pulses control the duration of bistable multivibrator output which is equal to the A-V interval. Finally, the negative moving ramp is the integrated output of the recorder. B: Relation between $\mathrm{R}-\mathrm{R}$ interval (upper tracing) and the $\mathrm{A}-\mathrm{V}$ interval (lower tracing). Ordinate numerals are msec. $\mathrm{C}$ : Circuit of $\mathrm{A}-\mathrm{V}$ interval meter: $\mathrm{T}_{1}$, $\mathrm{T}_{2}$ and $\mathrm{T}_{3}$ are $2 \mathrm{~N} 3391$.

were used for stimulation of the nerves. In anesthetized dogs, the vagi were transected bilaterally in the neck. The stellate ganglions were dissected from surrounding tissue bilaterally, their preganglionic nerves transected, and the ganglion laid on the electrodes and stimulated. Since extracellular stimulation of the nerve bundles was used, the intensity of stimulation could not be measured quantitatively. Care was taken to record constant waveforms of the myocardial action potentials, especially the rising phase of the action potentials in order to trigger the integrator regularly. The monophasic potential of a proper wave form and amplitude recorded by the suction electrodes usually did not last over 40 minutes. Long term monitoring of the original action potentials was essential to our experimental design. In the anesthetized preparation the electrode could be easily and quickly reapplied to recover the appropriate action potentials. The accuracy of the interval meter was also checked by measuring the triggering levels using the oscilloscope. Finally, the A-V intervals were calibrated on the oscilloscope. 


\section{RESULTS}

\section{$A-V$ interval in intact unanesthetized animal}

The term "A-V interval" in this paper refers to the time interval between the beginning of the atrial spike and the beginning of the ventricular spike. During this interval, excitation was initiated from the S-A node and conducted through the atrial tissue, A-V node, and Purkinje fibers. This interval ranged from 80 to $200 \mathrm{msec}$, depending on the subject and conditions (BURCH and WINSOR, 1960). However, during several consecutive cardiac cycles in the same subject under resting conditions, the $\mathrm{A}-\mathrm{V}$ interval often varied so little that consecutive $\mathrm{P}$ waves can be superimposed when the recorded ECG is played back in reverse and the QRS spike used for triggering (BRODY et al., 1967; IRISAWA and SEYAMA, 1966). Therefore, the conspicuous arrhythmia of respiratory origin frequently observed in resting unanesthetized dogs precludes the concept of "constant conditions." Figure 2-A illustrates the simultaneous recording of R-R and

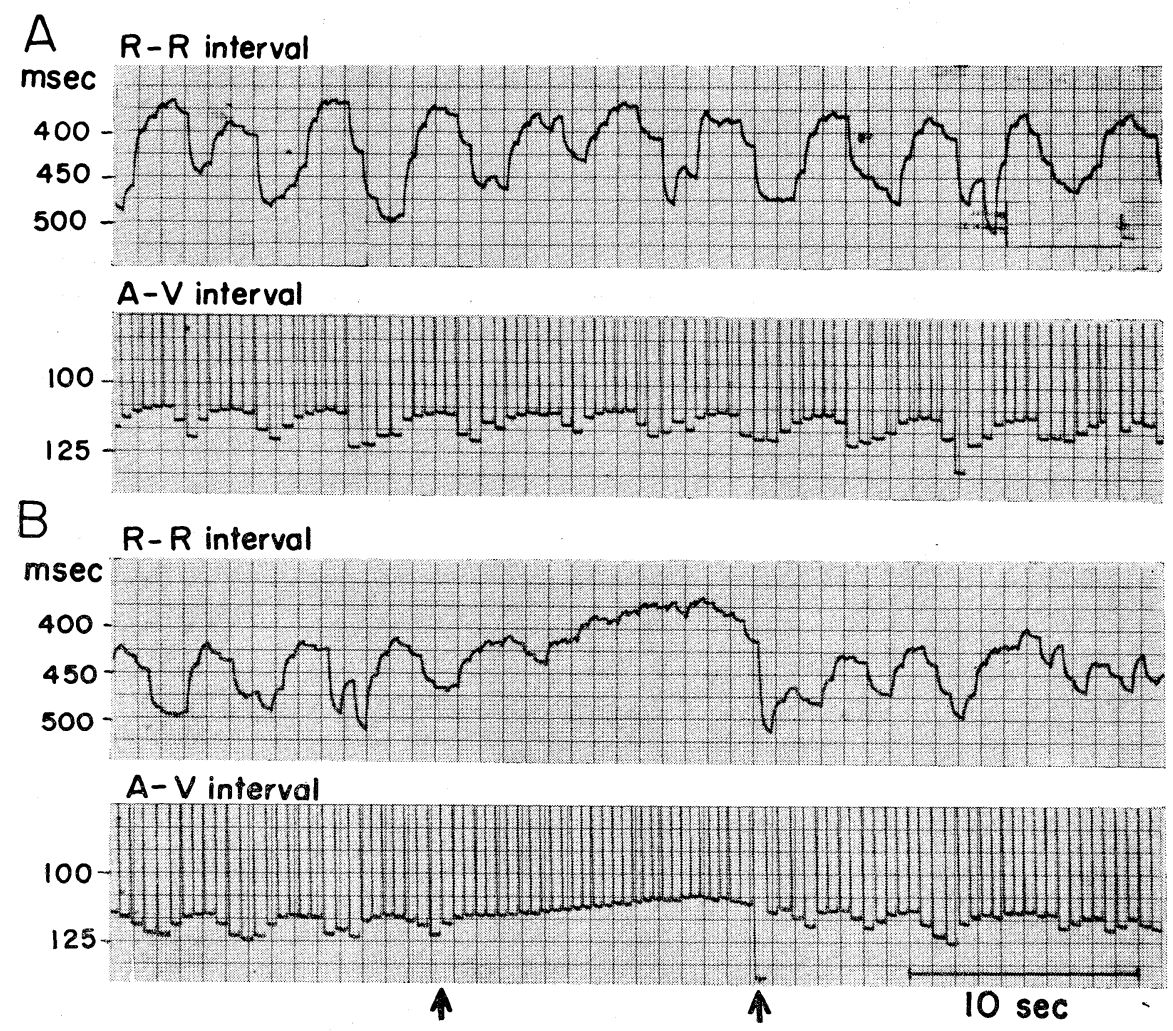

Fig. 2. In $\mathrm{A}$, the respiratory undulation of the $\mathrm{R}-\mathrm{R}$ interval (upper tracing) and the $\mathrm{A}-\mathrm{V}$ interval (lower tracing), obtained from a dog 24 hours after the operation. Large variation in the $\mathrm{R}-\mathrm{R}$ interval was characteristic in the post-operative dog. 
A-V intervals in resting, post-operative dogs. It also shows that the respiratory variation of these intervals was proportional in magnitude and was in phase. Figure 2-B illustrates the effect of a sustained increase in heart rate on these variations when the dog stood up with its forelegs elevated. Both intervals were shortened, and respiratory variations diminished. When the dog was permitted to recline again, there was an immediate reappearance of the arrhythmia seen in both intervals. A similar pattern of response was observed during drinking and eating.

\section{Effect of blocking agents}

The respiratory variation in the $\mathrm{R}-\mathrm{R}$ and $\mathrm{A}-\mathrm{V}$ intervals grew slighter after administration of $0.5 \mathrm{mg} / \mathrm{kg}$ propranolol (Fig. 3-A). The A-V interval was prolonged by about $10 \mathrm{msec}$ suggesting that tonic sympathetic nerve discharge was partially controlling the $\mathrm{A}-\mathrm{V}$ conduction time in the resting unanesthetized dog. The postual change in both intervals was largely suppressed after the administration of the propranolol (Fig. 3-B). After the administration of $0.1 \mathrm{mg} / \mathrm{kg}$ atropine, the respiratory variation in the $\mathrm{R}-\mathrm{R}$ and $\mathrm{A}-\mathrm{V}$ intervals completely disappeared (Fig. 3-C). The R-R interval became progressively shorter, while the A-V interval was initially shortened, then gradually prolonged. Under the effect of atropine and pretreatment with propranolol, postural changes still increased slightly, as is shown in Fig. 3-D.
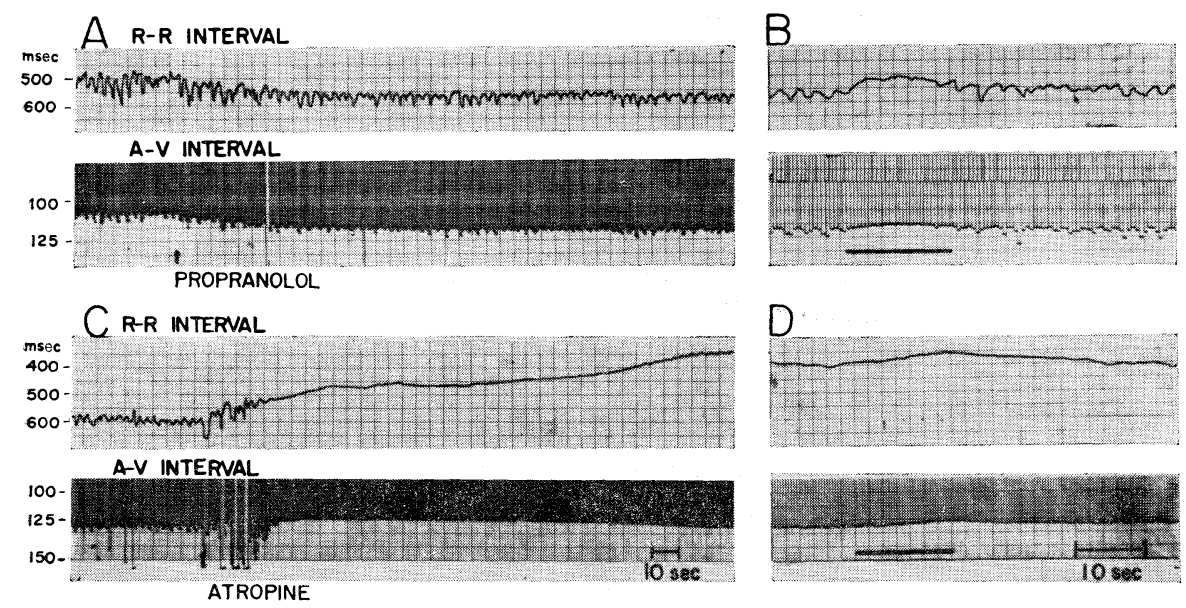

Fig. 3. A: Changes in $\mathrm{R}-\mathrm{R}$ and $\mathrm{A}-\mathrm{V}$ intervals after the administration of propranolol. $\mathrm{B}$ : the postural stimulation was performed during the period shown in bar under the $A-V$ interval tracings, 15 minutes after treatment with propranolol. $\mathrm{C}$ : one hour after $\mathrm{B}$, atropine was given at the arrow to the same dog that received the propranolol (panels $\mathrm{A}$ and $\mathrm{B}$ ), and $\mathrm{D}$ : the postural stimulation was given under the effect of atropine. In $\mathrm{C}$, shortly after atropine was administrated, the A-V interval was prolonged and exceeded $150 \mathrm{msec}$. This extreme prolongation is partly due to the $\mathrm{A}-\mathrm{V}$ block and to the effect due to the movement of the electrodes. 


\section{Relationship of $R-R$ and $A-V$ intervals under anesthesia}

After the administration of sodium pentobarbital the respiratory variation of the $\mathrm{A}-\mathrm{V}$ interval was essentially eliminated. When the $\mathrm{R}-\mathrm{R}$ interval was increased in a stepwise manner (Fig. 4-A) or as a ramp function (Fig. 4-B), by changing the driving rate of the stimulation to the right atrium, an inverse relationship between the $\mathrm{R}-\mathrm{R}$ interval and the $\mathrm{A}-\mathrm{V}$ interval was observed. Thus the variations of the $R-R$ and $A-V$ intervals under the control of the vagal and sympathetic nerves were in phase, while those variations not under automatic control, viz., with pacing and after pharmacological blockadge, were out of phase. This
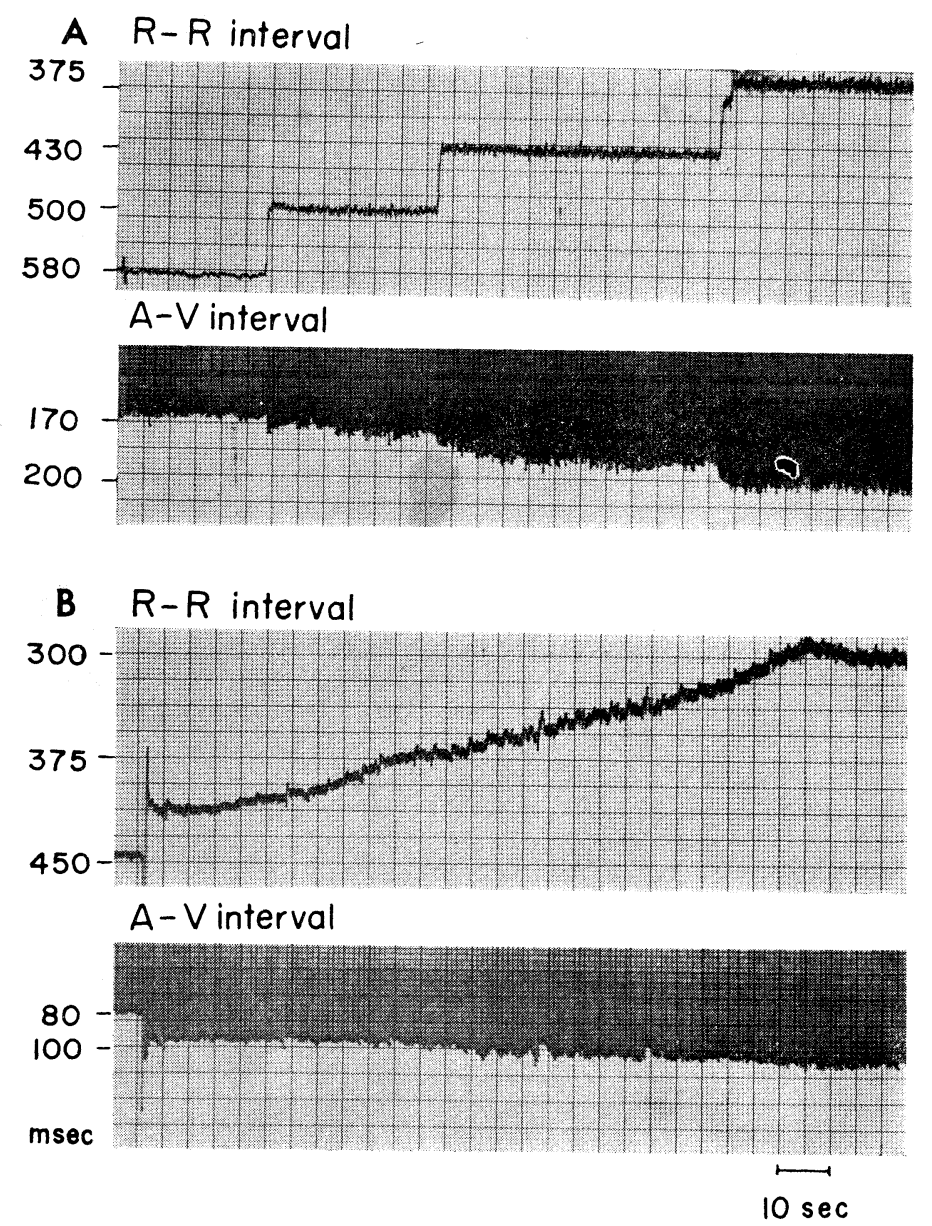

Fig. 4. Effect of electrical pacing of right atrium on the $\mathrm{A}-\mathrm{V}$ interval. $\mathrm{A}: \mathrm{R}-\mathrm{R}$ interval was changed by the stimulation frequency of $1.7 / \mathrm{sec}, 2 / \mathrm{sec}, 2.3 / \mathrm{sec}$ and $2.7 / \mathrm{sec}$ stepwise. $\mathrm{B}$ : At the onset of electrical pacing of the right atrium the $\mathrm{R}-\mathrm{R}$ interval was shortened and the $\mathrm{A}-\mathrm{V}$ interval was lengthened abruptly. As the $\mathrm{R}-\mathrm{R}$ interval was gradually shortened further, due to increased pacing frequency, the A-V interval slowly grew longer. 
idea is consistent with previous observations (LISTER et al., 1965; MoE et al., 1956; SCHER et al., 1959).

\section{Effect of vagal stimulation on the A-V interval}

Figure 5 illustrates a typical experimental result showing the difference in response to right vagal stimulation (R.V.S.) and left vagal stimulation (L.V.S.). In spite of the sudden and extreme lengthening of the R-R interval during R.V.S. no significant prolongation was observed in the A-V interval. On the other hand, no obvious change in the $\mathrm{R}-\mathrm{R}$ interval was observed during L.V.S., while a gradual prolongation of greater than $15 \mathrm{msec}$ was observed in the A-V interval. This figure also demonstrates that a change in sinus node frequency to R.V.S. was nearly instantaneous, while the response time for a change in A-V transmission was measurable in seconds. In four different animals, 40 stimuli were applied to the left vagus nerve and 30 were applied to the right vagus nerve. The intensity of stimuli was as small as possible so that A-V conduction was not blocked. The effect on the R-R interval was generally greater with R.V.S. than with L.V.S. On the other hand, the effect of L.V.S. on the A-V interval was greater than that

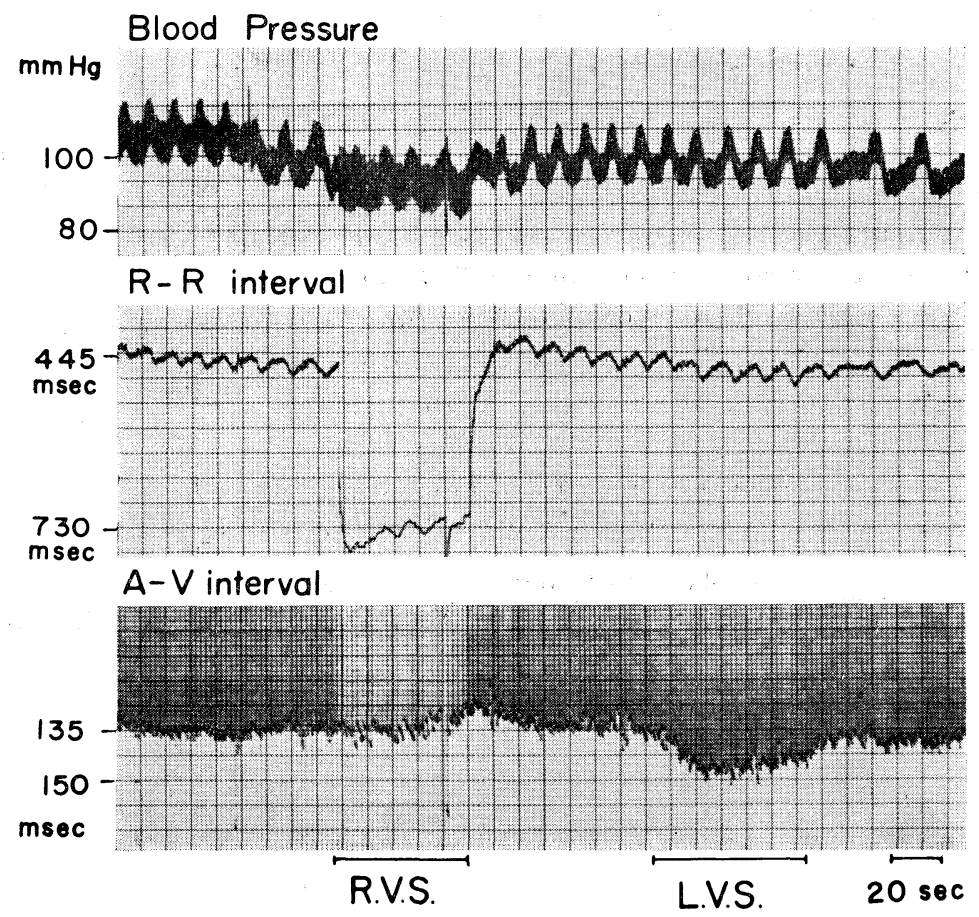

Fig. 5. Effect of vagal stimulation. Top: Blood pressure from left carotid artery. Middle: R-R interval. Bottom: A-V interval, R.V.S. (right vagal stimulation), L.V.S. (left vagal stimulation). 
Table 1. Comparison of the left and right vagal nerve stimulation on the $R-R$ and $P-R$ intervals.

\begin{tabular}{clcccccc}
\hline $\begin{array}{c}\text { Number } \\
\text { of } \\
\text { dog }\end{array}$ & $\begin{array}{c}\text { Vagus } \\
\text { nerve } \\
\text { stimulation }\end{array}$ & $\begin{array}{c}\text { Number } \\
\text { of } \\
\text { experi- } \\
\text { ments }\end{array}$ & $\begin{array}{c}\text { Increase } \\
\text { of R-R } \\
\text { interval } \\
(\%) \text { Ranges }\end{array}$ & $\begin{array}{c}\text { Mean } \\
(\%)\end{array}$ & $\begin{array}{c}\text { Increase } \\
\text { of A-V } \\
\text { interval } \\
(\%) \text { Ranges }\end{array}$ & $\begin{array}{c}\text { Mean } \\
(\%)\end{array}$ & Remarks \\
\hline 1 & Left & 7 & $0-30$ & 13 & $12-35$ & 16 & \\
\hline 2 & Right & 5 & $20-35$ & 28 & $0-4$ & 2 & \\
\hline 3 & Left & 6 & $27-50$ & 36 & $14-30$ & 21 & \\
& Right & 11 & $15-60$ & 43 & $0-8$ & 2 & \\
\hline 4 & Left & 13 & $0.6-13$ & 7.8 & $1-30$ & 16 & \\
\hline & Right & 4 & $26-33$ & 30 & $0-15$ & 11 & 1 instance \\
& Left & 14 & $12-35$ & 21 & $6-24$ & 15 & \\
\hline
\end{tabular}

of R.V.S. (Table 1). When the intensity of the stimulus was increased, the R-R interval was also prolonged during L.V.S. and A-V blocking occurred.

\section{Effect of sympathetic nerve stimulation on $A-V$ interval}

Stimulation of the sympathetic nerve caused shortening of the A-V interval (Fig. 6). With right stellate ganglion stimulation (R.S.S.), the R-R interval was reduced by $240 \mathrm{msec}$ and the $\mathrm{A}-\mathrm{V}$ interval was reduced by about $10 \mathrm{msec}$. The response time of the change in the $\mathrm{R}-\mathrm{R}$ interval to R.S.S. was slower than that of vagus nerve stimulation. The response time of the reduction of the A-V interval was similar to that of the $\mathrm{R}-\mathrm{R}$ interval. The peak response in $\mathrm{A}-\mathrm{V}$ interval arrived before the peak response of the $\mathrm{R}-\mathrm{R}$ interval and then declined with a complex time course. Left stellate ganglion stimulation (L.S.S.) caused no obvious change in the $\mathrm{R}-\mathrm{R}$ interval in spite of the evident reduction of the $\mathrm{A}-\mathrm{V}$ interval. After L.S.S. was suspended, the return to the control level occurred with a time

Table 2. Comparison of the left and right stellate ganglion stimulation on the $\mathrm{R}-\mathrm{R}$ and $\mathrm{P}-\mathrm{R}$ intervals.

\begin{tabular}{clcccccc}
\hline $\begin{array}{c}\text { Number } \\
\text { of } \\
\text { dog }\end{array}$ & $\begin{array}{c}\text { Stellate } \\
\text { ganglion } \\
\text { stimulation }\end{array}$ & $\begin{array}{c}\text { Number } \\
\text { of } \\
\text { experi- } \\
\text { ments }\end{array}$ & $\begin{array}{c}\text { Reduction } \\
\text { of R-R } \\
\text { interval } \\
(\%) \text { Ranges }\end{array}$ & $\begin{array}{c}\text { Mean } \\
(\%)\end{array}$ & $\begin{array}{c}\text { Reduction } \\
\text { of A-V } \\
\text { interval } \\
(\%) \text { Ranges }\end{array}$ & $\begin{array}{c}\text { Mean } \\
(\%)\end{array}$ & Remarks \\
\hline 1 & Left & 13 & $0-10$ & 0.1 & $5-8$ & 13 & 3 block \\
\hline 2 & Right & 6 & $20-30$ & 26 & $6-12$ & 10 & \\
\hline 3 & Left & 7 & 0 & 0 & $19-25$ & 23 & \\
\hline 4 & Right & 7 & $14-36$ & 22 & $5-22$ & 10 & \\
\hline & Left & 9 & $0-24$ & 5 & $10-12$ & 11 & 2 block \\
& Right & 6 & $24-50$ & 31 & $4-16$ & 8 & \\
\hline
\end{tabular}




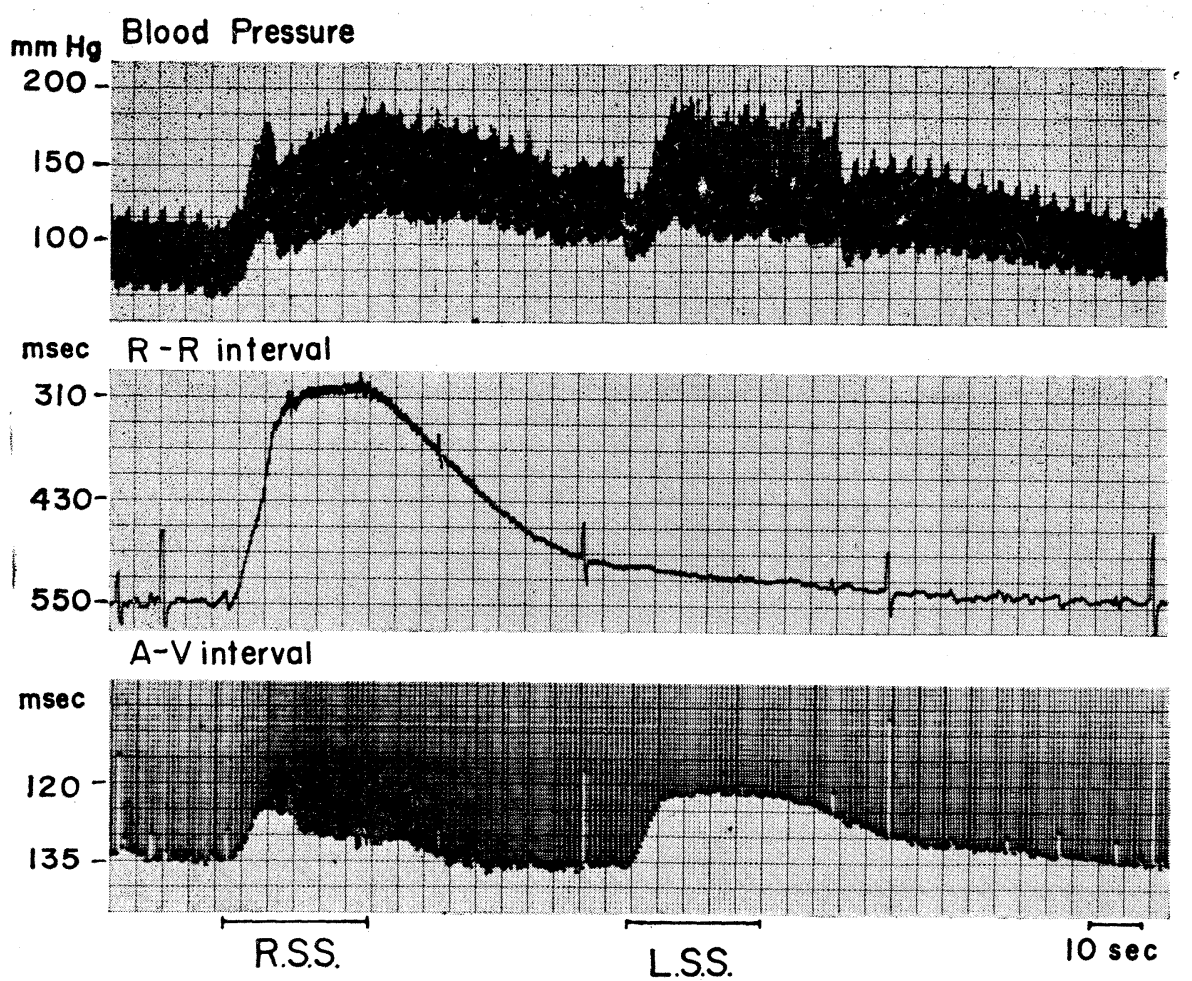

Fig. 6. Effect of stellate ganglion stimulation. R.S.S. (right stellate stimulation), L.S.S. (left stellate stimulation).

course of over one minute. Both R.S.S. and L.S.S. caused an increase in blood pressure (Fig. 6 top tracing). When the A-V interval was shortened severely, the A-V conduction block was achieved. In Fig. 6, however, A-V conduction was still orthodromic. In four different animals, 33 stimuli were applied on the left stellate ganglion. In these experiments, the effect on the $\mathrm{R}-\mathrm{R}$ interval was always greater with R.S.S. than with L.S.S. On the other hand, the effect of left stellate ganglion stimulation on the A-V interval was greater than that of stimulation of the right (Table 2).

\section{DISCUSSION}

In the post-operative unanesthetized dog, the variation of the $\mathrm{A}-\mathrm{V}$ interval was $\pm 10 \mathrm{msec}(10 \%)$ when the $\mathrm{R}-\mathrm{R}$ interval varied $\pm 100 \mathrm{msec}(20 \%)$, supporting the concept that the atrioventricular transmission rate is more stable than fluctuations in the S-A node frequency. The small variation in the A-V transmission rate is probably not only due to the opposing influences of the heart rate and autonomic neural control on $\mathrm{A}-\mathrm{V}$ node conduction. For example, and increase 
in heart rate by pacing caused a prolongation of $\mathrm{A}-\mathrm{V}$ conduction time. However, under normal conditions an increased heart rate is produced by a decrease in vagal activity and an increase in sympathetic activity, which in themselves tend to shorten A-V conduction time. Such balancing influences furnish a safety mechanism for the regulation of the cardiac output.

HOFFMAN and SINGER (1967) administered $2 \mathrm{mg} / \mathrm{kg}$ pronethalol to the isolated $\mathrm{A}-\mathrm{V}$ node and found a shortening of $\mathrm{A}-\mathrm{V}$ conduction time. With larger doses (15 to $25 \mathrm{mg} / \mathrm{kg}$ ), the conduction time progressively increased. In the intact unanesthetized animal, a slight prolongation of the A-V interval was obtained by administering $0.5 \mathrm{mg} / \mathrm{kg}$ propranolol. This suggests that the sympathetic nervous activity tonically influences $\mathrm{A}-\mathrm{V}$ conduction time, although reservations may be necessary considering the direct action of propranolol on A-V conduction. Further experiments should be performed to ascertain the validity of this suggestion. A more marked change in the A-V interval was observed when atropine was administered, the respiratory variation being completely eliminated. These observations demonstrate that not only the S-A node but also the A-V node are under the homeostatic control of the sympathetic and the vagal nerves.

Bilateral recordings of cardiac sympathetic nerve activity in the cat have demonstrated that the left and right sympathetic outflow to the heart are synchronous (BRONK et al., 1936). In the present study, stimulation of the right stellate ganglion shortened mainly the A-V interval. Therefore, these different effects on cardiac condution time must be explained partly on the basis of the distribution of sympathetic nerves in the heart (KunTZ, 1953). Such differences in cardiac sympathetic innervation between the right and left sides have even been found higher in the central nervous system, where stimulation of the right dorsal medulla caused mostly cardio-acceleration, whereas augmentation of cardiac contraction resulted from stimulation of the left dorsal medulla (CHAI and WANG, 1962). Such responses to sympathetic and vagal nerve stimulation suggest that anatomical differences in their distribution in the heart contribute to the delicate control of the cardiac output.

\section{REFERENCES}

Anzola, J. and Rushmer, R. F. (1956) Cardiac responses to sympathetic stimulation. Circ. Res., 4: 302-307.

Brody, D. A., Arzbaecher, R. C., Woolsey, M. D. and Sato, T. (1967) The normal atrial electrocardiogram: Morphologic and quantitative variability in bipolar extremity leads. Am. Heart J., 74: 4-12.

Bronk, D. W., Ferguson, L. K., Margaria, R. and Solandt, D. Y. (1936) The activity of the cardiac sympathetic centers. Am. J. Physiol., 117: 237-249.

Burch, G. E. and Winsor, T. (1960) A primer of electrocardiography. 4th edition Lea \& Febiger, Philadelphia.

CHAI, C. Y. and WANG, S. C. (1962) Localization of central cardiovascular control mechanism in lower brain stem of the cat. Am. J. Physiol., 202: 25-30. 
Cranefield, P. F., Hoffman, B. F. and A. Paes De Carvalho, (1959) Effects of acetylcholine on single fibers of the atrio-ventricular node. Circ. Res., 7: 19-23.

Hoffman, B. F. and Singer, D. H. (1967) Appraisal of the effects of catecholamines on cardiac electrical activity. Ann. N.Y. Acad. Sci., 139: Art 3, 914-939.

IrisawA, H. and SeYAmA, I. (1966) The configuration of the P wave during mild exercise. Am. Heart J., 71: 467-472.

KunTZ, A. (1953) Innervation of the heart. In Autonomic Nervous System, 4th edition, Lea and Febiger, Philadelphia, 135-151.

Lister, J. W., Stein, E., Kosowsky, B. D., IAU, S. H. and Damato, A. N. (1965) Atrioventricular conduction in man. Effect of rate, exercise, isoproterenol and atropine on the P-R interval. Am. J. Cardiol., 16: 516-523.

Moe, G. K., Preston, J. B. and Burlington, H. (1956) Physiologic evidence for a dual A-V transmission system. Circ. Res., 4: 357-375.

Priola, D. V. and Randall, W. C. (1964) Alterations in cardiac synchrony induced by the cardiac sympathetic nerves. Circ. Res., 15: 463-472.

RANDAll, W. C. and RohSE, W. G. (1956) The augmentor action of the sympathetic cardiac nerves. Circ. Res., 4: 470-475.

Randall, W. C., Priola, D. V. and Ulmer, R. H. (1963) A functional study of the distribution of cardiac sympathetic nerves. Am. J. Physiol., 205: 1227-1231.

RUSHMER, R. F. and WeST, T. C. (1957) Role of autonomic hormones on left ventricular performance continuously analyzed by electronic computors. Circ. Res., 5: 240-246.

Scher, A. M., Rodriguez, M. I., LiIAne, J. and Young, A. C. (1959) The mechanism of atrioventricular conduction. Circ. Res., 7: 54-61.

Shipley, R. E. and GregG, D. E. (1945) The cardiac response to stimulation of stellate ganglia and cardiac nerves. Am. J. Physiol., 143: 396-401.

ULMER, R. H. and RANDALl, W. C. (1961) Atrioventricular pressures and their relationship during stellate stimulation. Am. J. Physiol., 20: 134-138.

Wallace, A. G. (1963) Sympathetic influences on conduction in the intact heart. Fed. Proc., 22: 578 .

Wallace, A. G. and Sarnoff, S. J. (1964) Effect of cardiac sympathetic stimulation on conduction in the heart. Circ. Res., 14: 86-92.

Wilson, M. F. and NinOmiYA, I. (1964) Left ventricular dimension-flow correlations in the instrumented dog. Proc. San Diego Symp. Biomed. Engr., 4: 224-232. 